Diogo Bonioli Alves Pereira

\title{
Formação Continuada para Professores Imigrantes Digitais: Desenvolvendo uma Nova Linguagem Didática para a Inserção das Tecnologias Educacionais na Sala de Aula
}

Trabalho de Conclusão de Curso

Coordenação Central de Educação a Distância PÓS-GRADUAÇÃO LATO-SENSU Tecnologias em Educação 
Formação continuada para professores imigrantes digitais: desenvolvendo uma nova linguagem didática para a inserção das tecnologias educacionais na sala de aula

Trabalho de conclusão de curso apresentado à Coordenação do Curso de Especialização Tecnologias em Educação como requisito parcial para obtenção de título de Especialista em Tecnologias em Educação

Orientador

Prof.‥ Tiago da Silva Ribeiro

Coordenação Central de Educação a Distância Curso de Especialização Tecnologias em Educação 


\section{Dedicatória}

Ao meu filho Gustavo Bazílio Bonioli Pereira, minha dedicatória, pela oportunidade de me fazer experimentar a mais pura forma de amor, único que toca o infinito. Aqui registro parte das minhas crenças, valores que almejo te ensinar. O fundamental está invisível aos olhos, mas perpassa constantemente estas linhas: acredite na capacidade de mudança dos seres humanos, nossos semelhantes. Por fim, não seja como eu, seja melhor do que eu, mas sendo sempre você, pois sendo você já está sendo aquele que amo. Agradeço a compreensão pelas ausências por causa dos estudos, mas saiba que agora você é a razão dos meus esforços.

À minha Mãe Professora Rosemery Bonioli Pereira, ou Tia Rose, aquela que me ensinou que a educação e o ensino são os melhores, senão os únicos, caminhos para que o ser humano possa se desenvolver. Esta é a sua inesquecível lição que não é ensinada nas universidades: sorrir, conversar, cumprimentar, se preocupar com alunos e ser simpático não depõe contra um professor intelectual, que o currículo formal sem afeto produz aprendizagem deficiente e que só a partir disso é que fazemos a diferença, pois só pela doçura criamos laços eternos.

À minha Amiga e Diretora Vera Maria Savaget Barreiros. Mestra. Aquele que orientou minha prática e relembrou as lições da minha mãe. Dedico este trabalho, pois você é modelo de professora e gestora, e, por ter me dado mais oportunidades do que mereço para mostrar o meu trabalho. A possibilidade de investir meus esforços aqui é o resultado de incansavelmente me recordar que nossa profissão modifica vidas e que assim possibilitamos o surgimento de novas histórias. Com este trabalho escreveremos ainda mais belas histórias.

À Profa Ana Maria (in memoria), que nos deixou no ano em que este curso acontecia, minha dedicatória por nos ensinar que todos podem aprender, que afabilidade, calor e ternura são os condutores do ensino e que não existe professor sem caridade e espiritualidade. 


\section{Agradecimentos}

Ao $\underline{\text { Senhor Jesus Cristo, }}$ meu pastor e companheiro e a Nsa Sra da Cabeça, minha mãe e padroeira que me ilumina nesta caminhada intelectual e profissional. Não esqueceria Santa Luzia, padroeira da nossa escola e a marcou colocando o único CAT com nome de santa.

À minha esposa Gisele Bazílio Silva Bonioli pela paciência, incentivo e apoio total para o tempo deste estudo e produção deste Trabalho de Conclusão. Obrigado por me lembrar do que sou capaz quando por algumas vezes eu esqueço. O verdadeiro amor não é se transformar ao estar com alguém para nosso benefício, mas quando nos transformamos para alguém porque estamos com ele para benefício dos outros.

Ao Sistema Firian que possibilitou esta especialização. Obrigado pelo investimento e consideração para comigo e meus colegas, de fato "vestimos a camisa" desta empresa, gostamos do que fazemos porque temos liberdade para sermos o que somos e por isso nos sentimos como em família.

A Sheilane M. de Avellar Cilento R. de Britto, nossa atenciosa mediadora. Obrigado pela paciência, conselhos, direcionamentos e principalmente pela sua disponibilidade e carinho. Agradeço a toda equipe da CCEAD PUC-RIO, os Ocultos, que não vemos, mas sabemos que existem.

Aos colegas professores e pedagogos do SESI, da Unidade Cinelândia, pelo apoio, confiança e credibilidade no trabalho desenvolvido.

Por fim, e não menos importante: OBRIGADO AOS MEUS ALUNOS! São vocês as razões de tudo isso. Obrigado por vocês me ensinarem a ser professor! 


\section{Resumo}

As Tecnologias da Informação e da Comunicação (TIC's) já são parte integrante do cotidiano da sociedade contemporânea e a popularização da internet as tornou necessárias na medida em que faz surgir diferentes formas de comunicação, relacionamentos e construção do conhecimento, em uma linguagem nova e exclusiva. Em contrapartida a Escola, pouco tem acompanhado este processo e insiste em oferecer uma didática conservadora e conteudista. Este conflito cultural, segundo pesquisas, forma a principal razão da evasão escolar. Para promover uma nova linguagem didática que transforme as TIC's em Tecnologias Educacionais que possa favorecer o processo de ensinoaprendizagem é que voltamos nosso olhar para o professor, que em sua maioria são imigrantes digitais e que precisam tanto ser iniciados na formação básica para o uso das TIC's, bem como serem nutridos de conhecimento pedagógico e cultural que sejam suficientes para diminuir o espaço existente entre sua formação inicial e a realidade da cultura digital que se impõem na sala de aula. Este trabalho propõe um plano de Formação Continuada para Professores Imigrantes Digitais, maior parte dos regentes, a fim de produzirem um novo posicionamento didático que favoreça melhores resultados em aprendizagem e possam dar conta das demandas modernas do aluno, da sociedade, do mundo globalizado, assim como das profissões, doenças e questões que ainda surgirão mediante este crescimento vertiginoso do conhecimento e das TIC's.

\section{Palavras-chave: Formação Continuada; Tecnologias Educacionais; Desing Instrucional}

Resumen: Las Tecnologías de la Información y la Comunicación (TIC) son ya parte integrante de la vida cotidiana de la sociedad contemporánea y la popularización de internet las ha hecho necesarias ya que hace emerger diferentes formas de comunicación, relaciones y construcción del conocimiento, en un lenguaje nuevo y exclusivo. . Por otro lado, la Escuela ha seguido poco este proceso e insiste en ofrecer una didáctica conservadora y contenciosa. Este conflicto cultural, según las investigaciones, constituye la principal razón del abandono escolar. Para impulsar un nuevo lenguaje didáctico que transforme las TIC en Tecnologías Educativas que puedan favorecer el proceso de enseñanza-aprendizaje, dirigimos nuestra atención al docente, que en su mayoría son inmigrantes digitales y que ambos necesitan iniciarse en la formación básica para el uso de las TIC, como además de nutrirse de conocimientos pedagógicos y culturales suficientes para reducir la brecha entre su formación inicial y la realidad de la cultura digital que se impone en el aula. Este trabajo propone un plan de Educación Continuada para Docentes Inmigrantes Digitales, la mayoría de los conductores, con el fin de producir un nuevo posicionamiento didáctico que favorezca mejores resultados en el aprendizaje y pueda hacer frente a las demandas modernas del alumno, la sociedad, el mundo globalizado, así. así como las profesiones, enfermedades y problemas que aún surgirán debido a este vertiginoso crecimiento del conocimiento y las TIC.

Palabras clave: Educación Continuada; Tecnologías educativas; Diseño instruccional 


\section{Lista de Tabelas}

TABELA 1: PLANEJAMENTO DAS HABILIDADES E COMPETÊNCIAS DO CURSO BÁSICO EM TI PARA PROFESSORES

TABELA 2: REFERÊNCIAS COMPLEMENTARES DO CURSO DE FORMAÇÃO BÁSICA EM TI BÁSICO PARA PROFESSORES

TABELA 3: PLANEJAMENTO DAS HABILIDADES E COMPETÊNCIAS DA FORMAÇÃO CONTINUADA EM TECNOLOGIAS EDUCACIONAIS

TABELA 4: REFERÊNCIAS COMPLEMENTARES DA FORMAÇÃO CONTINUADA EM TECNOLOGIAS EDUCACIONAIS

TABELA 5: RECURSOS HUMANOS E MATERIAIS PARA O CURSO BÁSICO EM TI PARA PROFESSORES

TABELA 6: RECURSOS HUMANOS E MATERIAIS PARA A FORMAÇÃO EM TECNOLOGIAS EDUCACIONAIS

TABELA 7: CRONOGRAMA GERAL DA FORMAÇÃO CONTINUADA PARA PROFESSORES IMIGRANTES DIGITAIS 


\section{Lista de Figuras}

FIGURA 1: VERTENTES DO PROGRAMA CONECTIVIDADE DO SISTEMA FIRJAN.

FIGURA 2: VOCÊ ACREDITA QUE A INCLUSÃO DAS TECNOLOGIAS DA INFORMAÇÃO E COMUNICAÇÃO (TIC'S) FAVORECEM A EDUCAÇÃO?

FIGURA 3: NA SUA FORMAÇÃO INICIAL VOCÊ ESTUDOU SOBRE TECNOLOGIAS

EDUCACIONAIS?

FIGURA 4: ANTES DAS OFICINAS DE TECNOLOGIAS EDUCACIONAIS OFERECIDAS PELO SESI

VOCÊ SE SENTIA PREPARADO(A) PARA UTILIZAR AS TIC'S NA SALA DE AULA?

FIGURA 5: VOCÊ ACREDITA QUE SEJA NECESSÁRIO UMA NOVA POSTURA DIDÁTICA PARA A

UTILIZAÇÃO DAS TECNOLOGIAS EDUCACIONAIS NA SALA DE AULA?

.22

FIGURA 6: ESTRUTURA DA FORMAÇÃO CONTINUADA - ÊNFASE NA FORMAÇÃO BÁSICA .......26

FIGURA 7: ESTRUTURA DA FORMAÇÃO CONTINUADA - ÊNFASE NA FORMAÇÃO

CONTINUADA EM TECNOLOGIAS EDUCACIONAIS 


\section{Sumário}

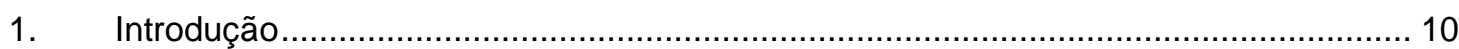

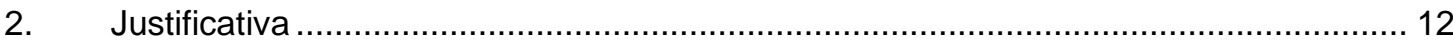

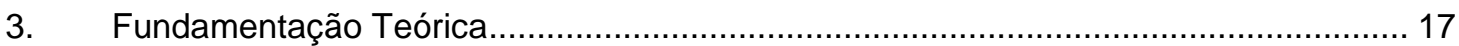

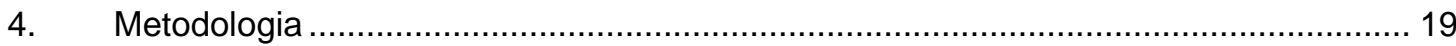

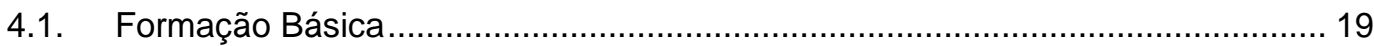

4.2. Formação Continuada em Tecnologias Educacionais ........................................ 21

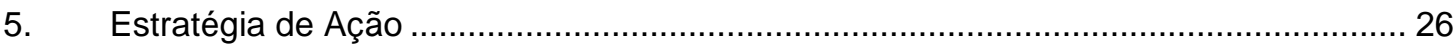

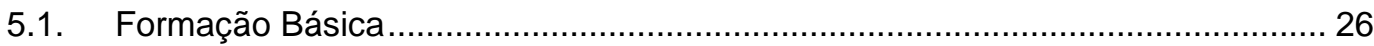

5.2. Formação Continuada em Tecnologias Educacionais ....................................... 28

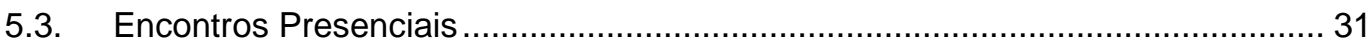

6. Cronograma

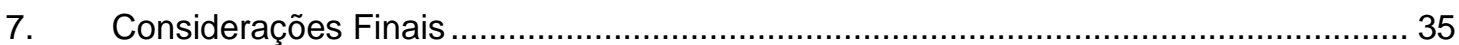

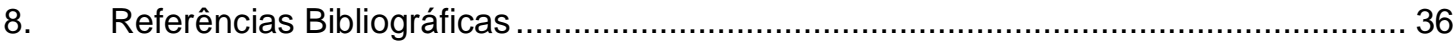

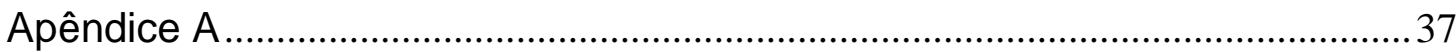


- Estranho quadro e estranhos prisioneiros são estes de que tu falas - observou ele.

- São semelhantes a nós - continuei (...)

- Considerai, pois - continuei - o que aconteceria se eles fossem soltos das cadeias e curados de sua ignorância (...)

Platão - Livro VII - A República 


\section{Introdução}

Em nossos dias torna-se impossível pensarmos no processo de ensino-aprendizado e o papel da escola sem que pensemos na relação da(s) cultura(s) interna da escola com a cultura existente além-muros. Efetivar a integração do sujeito à sociedade do conhecimento, da informação, da inovação e do compartilhamento são os novos desafios das práticas pedagógicas atuais. Assim fazse necessário pensarmos sobre que tipo de educação é oferecido aos nossos alunos e se de fato nossos esforços contribuem para o atual mercado ou ao antigo conceito de oferta de serviços.

As Tecnologias da Informação e da Comunicação (TIC's) presentes na sociedade precisam ser envolvidas no processo pedagógico como um elemento invisível e irruptivo que auxilie na prática pedagógica objetivando ampliar os resultados na educação e a virtualização da inteligência para a complexidade das exigências contemporâneas. Neste movimento encontramos o professor com a missão de preparar o seu aluno para uma sociedade que salta de um paradigma de postura local, isolada, consumidora; para as necessidades do século XXI, global, em equipe interativa, criadora e para o futuro de profissões e serviços que sequer ainda existem.

Poder contar com professores preparados para educar neste novo paradigma epistemológico é o diferencial que impulsionará o surgimento de personalidades inovadoras e empreendedoras, capazes de lidar com as novas exigências mundiais. Esta pesquisa pretende diminuir o espaço entre a formação inicial do professor, imigrante digital, e a realidade da cultura digital do aluno, nativo digital. Assim, propomos um modelo de Formação Continuada que objetiva diminuir esta lacuna gerando melhores resultados no processo de ensino-aprendizagem por reflexões de aplicações das TIC's à educação e assim encontrar soluções aos dilemas das práticas docentes, que contribui para maior qualidade de vida e trabalho do profissional da educação e melhores resultados de aprendizagem aos alunos.

Este projeto é justificado ao analisarmos os esforços históricos empreendidos para alcançar e garantir uma aprendizagem sem dispêndio de tempo e fadiga para professores e alunos. Apresentaremos dados relevantes de que ambos os resultados nunca sobrevieram, ao mesmo tempo em que apontamos a inserção das TIC's e a ressignificação da linguagem didática do professor, viabilizada por uma Formação Continuada, como meio eficaz de produzir os inéditos resultados de aprendizagem esperados na sala de aula.

Em seguida fundamentamos nosso objetivo na Formação Continuada do Docente investindo esforços na criação de novos e inovadores posicionamentos pedagógicos que possibilitam ao nosso público-alvo, os docentes imigrantes digitais, da Escola SESI Cinelândia, construírem modelos que permitam as TICs tornarem-se irruptivas, invisíveis e à serviço da maior qualidade no ensino e do saber/fazer docente.

Por fim expomos a metodologia e as estratégias de ação do Projeto de Formação Continuada para Professores Imigrantes Digitais que, divididas em duas etapas, pretende oferecer uma Formação Básica que ensine as ferramentas tecnológicas por si mesmas e em seguida a Formação Continuada em Tecnologias Educacionais, para o desenvolvimento da nova linguagem e postura 
didática. A metodologia destaca o conteúdo, as referências de carga horária, habilidades e competências necessárias, enquanto a estratégia demarca as ações em módulos, cronograma geral, recursos materiais e humanos. 


\section{Justificativa}

Assistimos durante a história da formação das sociedades inúmeras tentativas de estruturar uma técnica que fosse suficiente e universal que pudesse dar conta do processo de ensino e aprendizagem em sua integralidade e excelência. Imbuídos por este desejo sugiram inúmeros sistemas e metodologias que visavam garantir a eficácia da educação das crianças e jovens a fim de que se tornassem cidadãos ajustados às realidades sociais e contemporâneas, disponíveis e capazes para usufruir de seus direitos, cumprir os seus deveres e, se preciso fosse, conquistar as mudanças necessárias ao seu meio.

Segundo Fortaleza (2010), a primeira tentativa de formulação de uma metodologia, e que também marca o início da Idade Moderna para a Educação, foi a Didática de Comenius que, ao romper com o modelo de punições como técnica de reforço para a aprendizagem produzindo corpos dóceis, inova pela concepção de uma arte capaz de ensinar tudo a todos. Os retos princípios de Comenius foram dirigidos aos pais, aos professores, aos estudantes, às escolas, aos Estados, à Igreja e ao Céu, e dentre os seus objetivos destacamos: ensinar aos professores a arte de ensinar para que cumpram o seu dever de ensinar com sucesso, sem se esgotarem as suas forças ao trabalhar diligentemente e sem enfadonho dispêndio de tempo e fadiga; possibilitar aos alunos que "sem dificuldade, sem tédio, sem gritos e sem pancadas, como que divertindo-se e jogando, ser conduzidos para os altos cumes do saber" (2002[1621-1657], p. 47-8, p.48).

Sobre estes dois objetivos destacados da leitura de Comenius observamos que obtivemos poucos progressos. Em 2009, o Centro de Pesquisa Social da Fundação Getúlio Vargas, divulgou dados da pesquisa sobre os motivos da evasão escolar, com foco no público entre 15 a 17 anos, ao qual por meio de perguntas diretas, realizadas entre os anos de 2004 a 2008 chegaram as seguintes observações: existe uma considerável ausência de ciência do estudante sobre o alto impacto que a escolaridade provoca no salário; 40,7\% alegaram não terem interesse em frequentar a escola e não possuem interesses intrínsecos à educação; apenas 27,1\% alegam ter saído da escola por necessidade de trabalhar para auxiliar na renda familiar. Embora a evasão aumente por questões econômicas, destaca-se amplamente a falta de interesse como causa principal da evasão escolar.

O que provoca esta falta de interesse dos alunos? Vivemos no surgimento de uma nova lógica e configuração do modo de estar no mundo; de aprender, construir e constituir. Completamos, com as palavras de Leal et all, que:

A formação de conceitos numa base digital foi ressignificada. As crianças que nasceram no mundo tecnológico compreendem que podem ocupar diferentes lugares ao mesmo tempo, diminuindo as distâncias geográficas. A escola ainda não se dá conta disso e mantém os autores do processo [de] aprendizagem presos ao relógio mecanicista, cartesiano, do início da era moderna determinando a hora do pode e do não-pode, limitando a ação no espaço físico, negando a presença das tecnologias no cotidiano escolar e a extrapolação desse espaço. (2006, p. 22) 
Não é mais possível ignorar o espaço das TIC's na formação intelectual e da personalidade dos alunos e, desta forma, por vezes, não nos apercebermos dos impactos que isso trás aos professores. As TIC's possibilitam aos seus usuários autocriar-se e dar sentido à existência do coletivo potencializando em novas redes de relações marcados por vivências e linguagens diferenciadas. As Tecnologias auxiliam no desenvolvimento da autonomia do pensamento fazendo surgir novas concepções de vida, ética, arte e conhecimento; novas ciências, formas de pesquisas e relações políticas (Leal et all,2006), surge uma vida on-line, globalizada, com excesso de informações velozes e de comunicação ubíqua e interativa. Poder contar com professores preparados para educar nesta plataforma é o diferencial que impulsionará o surgimento de personalidades inovadoras e empreendedoras, capazes de lidar com as novas exigências mundiais.

A popularização do uso das TIC's introduz inovações no processo de ensinar e aprender, assim é necessário repensar as formas de ministrar aula. As políticas que contemplam a formação do professor devem situá-la neste novo processo que não são muito simples, pois o professor passa ser aliado do processo e as TIC's tornam-se protagonistas no movimento de criação das relações entre a escola e o mundo (ib).

Ao que neste momento nos perguntamos: Quais inovações e mudanças podem ser aplicadas na formação continuadas dos professores da Educação Básica para que possam se situar e usufruir das tecnologias, com melhor qualidade e de forma irruptiva, que colabore na construção de melhores resultados no processo de ensino-aprendizagem dos seus alunos?

Ao que concerne às questões dos professores, concordamos com Lelis (2008) acerca dos esforços que são feitos para mapear a problemática da sua formação, pois "não se trata apenas de um aumento de tempo de trabalho, mas de ampliação e diversificação das tarefas a que os professores são chamados a desempenhar" (ib, p.60), e tais desafios são compostos pelas novas políticas educacionais e os impactos das novas demandas socioculturais que os alunos trazem do seu cotidiano para a escola, aumentando o custo do professor para garantir a motivação na aula, sendo esta mobilização não tão assegurada como no passado. Assim, "o trabalho do professor passa a se inscrever em um novo quadro de relações, exigindo dele novas competências e habilidades" (ib).

Para preparar os docentes para os novos desafios das práticas pedagógicas é que entendemos a necessidade de voltarmos nossa reflexão sobre quais novas competências, saberes e atitudes seriam necessários aos professores desta sociedade do conhecimento a fim de elaborar processos de Formações Continuadas que promovam o desenvolvimento de competências para o imprevisto e ao inédito (ib, p.61), pois os desafios do século XXI exige dos alunos e professores uma nova postura, sobreadaptativa; humanista, planetária e sustentável, a partir de uma nova relação que o mercado impõem ao mesmo tempo que exige a ruptura da forma de pensamento e produção intelectual tradicional (MORIN, 2013)

Lelis objetivou decifrar algumas das tendências das produções intelectuais e, assim, explorar o conceito de "idiomas pedagógicos" como forma de prática docente construído a partir da relação entre teoria e cotidiano da sala de aula. No Brasil, nos últimos vinte anos foi possível observar uma mudança de uma pedagogia conteudista para uma perspectiva crítica ante a epistemologia da prática 
que contribui para o desenvolvimento da valorização da prática cotidiana como lugar de construção de saberes (2001, p.43).

Embora as produções acadêmicas apontem para esta mudança de saber, ainda encontramos dificuldades na aplicação dentro da prática docente que possam colaborar para o desenvolvimento de um ambiente favorável a uma educação coerente com as exigências modernas por seus novos sistemas de comunicação, comportamentos e formas de construir e compartilhar conhecimento.

Retornamos desta forma a questionar a necessidade de uma formação continuada aos professores para o desenvolvimento desta nova linguagem didática com as TIC's. Lelis (2008) analisa o programa de formação de Névoa que se apoia sobre o desenvolvimento de três grandes competências: (1) Saber relacionar e saber relacionar-se, trata-se do desenvolvimento de técnicas, e não de habilidade social, que afaste a burocracia da sala de aula e possibilite o professor construir uma identidade profissional que o torne animador e organizador de redes de aprendizagem ao qual ele será o agente que constrói situações educativas; (2) saber organizar e saber organizar-se, aqui trata-se do tornar o professor capaz de organizar um espaço de aprendizagem interpessoal, baseado nos princípios coletivos e, assim, inclusive, organizar novos dispositivos de avaliação a partir deste paradigma; (3) saber analisar e saber analisar-se, como uma competência associada ao conhecimento profissional, na dimensão teórica, e não só teórica, na dimensão prática, e não somente prática e na dimensão experiencial, mas não sendo esta a única fonte.

De modo análogo Campos et all (2007), consideram como fundamental pôr ênfase na formação de professores-multiplicadores, capazes de exercer autonomia e criatividade na sala de aula. Assim, apresentam o seu curso de Especialização em Tecnologias Educacionais, oferecidos pela CCEAD PUC-Rio, aos docentes para formá-los como futuros multiplicadores que por meio da especialização, atualização e aprofundamento das questões centrais que emanam dos princípios das integrações de mídias e a reconstrução da prática pedagógica. A proposta desta formação também se baseia em três competências, separados em eixo temáticos, a saber: (1) a escola como espaço integrador de mídias; (2) gestão de mídias na gestão escolar e (3) integração de tecnologias e mídias no fazer pedagógico.

O fenômeno da globalização como um processo histórico e político rendeu à sociedade contemporânea diversas mudanças, porém foram as TIC's que contribuíram para novos modos de subjetivação e individuação fundando uma nova concepção de mundo globalizado por novas formas de relacionamentos e socialização mediados por uma comunicação onde o sujeito não somente observa, mas interage, construindo e desconstruindo conhecimento(s) que se amplia e se distribui via compartilhamento, sintoma normal da nossa contemporaneidade (BONIOLI, 2012). Neste panorama compreendemos a emergência de se produzir formações continuadas que visem preparar os docentes para esta nova prática pedagógica. Trata-se de um novo posicionamento no mundo, na escola e na sala de aula. Baseados nos autores citados elaboramos um plano de formação que provoque a inovação dos atuais paradigmas educacionais, pelo uso de TIC's, e com isso contribuir para diminuição da evasão escolar, melhor qualidade no trabalho docente e melhores resultados na aprendizagem dos alunos. 
Paradoxalmente a facilidade de acesso ao conhecimento comunicado via TIC's produziram o rompimento de fronteiras físicas aproximando culturas distantes e distanciando relações fisicamente próximas. Neste contexto Provenzano e Waldhelm (2006) apontam para a criação de outras fronteiras, inclusive etnocêntrica, estabelecidas pelos parâmetros de plugados e não plugados e afirmam que:

(...) o conhecimento (e o poder inerente a ele) circula atravessando fronteiras e envolvendo novos cenários, enredos e personagens. [...] A grosso modo, podemos dizer que as tecnologias de informação conferem o passaporte ao conhecimento, mas o uso adequado, eficiente e crítico desta tecnologia é que pode garantir o visto de entrada e acesso qualificado a este saber (ib, p. 253)

Diante deste crescimento vertiginoso das TIC's da era digital percebemos que escola não pode se excluir desta realidade. Assim, somos convocados a desenvolver novos posicionamentos no plano didáticos, novos discursos pedagógicos, que não se atenham somente ao processo de transmissão e armazenamento do conhecimento, mas "à aprendizagem e utilização imediata das formas de acesso a conhecimento dispostos em terminais e redes digitais" (ib, p. 254) e que, por fim, possam favorecer o surgimento de uma nova cultura escolar atravessada pelas Tecnologias aplicadas à educação, de forma transparente e irruptiva.

Para promover esta mudança didática e escolar nos voltamos ao centro do saber docente, que, por excelência, reside no professor, objeto de nossa reflexão, ao qual deve estar - ou deveria inserido nesta nova forma de subjetivação, socialização, construção, compartilhamento e divulgação do conhecimento.

Os avanços tecnológicos comumente são vistos como um desafio aos que não são nativos digitais $^{1}$, e este embate torna-se ainda maior na nossa realidade, sendo o Brasil o quarto país com a maior população de nativos digitais contando mais de vinte milhões de jovens entre 15 e 24 anos, nascidos envolto a tecnologia digital (ITU, 2013). Assim temos um número excessivo de jovens nativos em detrimento de uma massa de docentes que são imigrantes digitais ou marginais às tecnologias, advindos de uma formação tradicional ou com pouca formação inicial em TIC's aplicadas à educação, ou simplesmente, tecnologias educacionais. Estes docentes vivem os desafios e dilema de um tempo de mudança.

Torna-se claro a existência de uma lacuna entre a linguagem/didática dos professores de formação tradicional ou de pouca tecnologia educacional, e dos alunos da modalidade regular - que se movimentam naturalmente pelo ciberespaço², dispositivos e nuvem ${ }^{3}$ - e EJA, imigrantes digitais que necessitam se adaptar ao mundo cada vez mais digital.

\footnotetext{
${ }^{1}$ Um nativo digital é aquele que nasceu e cresceu com as tecnologias digitais presentes em sua vivência. Tecnologias como videogames, Internet, telefone celular, MP3, iPod, etc. Caracterizam-se principalmente por não necessitar do uso de papel nas tarefas com o computador.

2 é um espaço existente no mundo de comunicação em que não é necessária a presença física do homem para constituir a comunicação como fonte de relacionamento, dando ênfase ao ato da imaginação, necessária para a criação de uma imagem anônima, que terá comunhão com os demais.

${ }^{3}$ Computação em nuvem: refere-se à utilização da memória e das capacidades de armazenamento e cálculo de computadores
} 
Segundo Martins e Girafa (2008, p. 3632)

(...) os professores que atuam na escola e possuem mais de vinte anos são imigrantes digitais no ciberespaço. Ou seja, nasceram em outro meio e aprenderam a construir conhecimento de forma diferente do que esta geração denominada de 'nativos' o faz.

São estes professores que voltamos nossa atenção, tanto por serem a maioria, quanto pela necessidade conceitual de desenvolvimento de uma educação que promova a autonomia. Porém, capacitar um docente para o uso da tecnologia como fim em si mesmo não é suficiente para que se tornem instrumentos de práticas educacionais.

Neste sentido que esta formação continuada do docente, ao qual propomos, privilegiará necessariamente explorar o desenvolvimento de habilidades e competências pedagógicas que faculte diminuir a diferença da forma de ensinar do professor imigrante para a forma de aprender e conhecer do seu aluno nativo, sem negligenciar a capacitação dos requisitos técnicos que envolvem o processo do uso básico dos instrumentos.

Em 2008 o programa PROINFO, do Ministério da Educação, implementou 5.000 laboratórios de informática em escolas públicas com projeto de expansão para 134.00 unidades escolares; o Projeto UCA (Um Computador por Aluno), do Governo Federal, teve como meta a distribuição de laptops para alunos e professores das escolas públicas. Em ambos os projetos a implementação e os resultados não foram satisfatórios, apontando que embora os recursos materiais sejam de suma importância, está na competência do docente à boa qualidade do ensino na escola e não na tecnologia em si (ib, 2008).

É de fato a Formação Continuada que contribui diretamente para o desenvolvimento do docente, tornando-o assim, indicador de melhorias educacionais e aponta para o contrário do senso comum, que coloca no aluno o principal e, por vezes, único problema da escola. 


\section{Fundamentação Teórica}

O objetivo deste projeto está em favorecer ao docente uma Formação Continuada que possibilite ampliar suas concepções pedagógicas sobre as TIC's e assim torná-las aplicáveis à educação como Tecnologias Educacionais. Proporcionar o desenvolvimento das competências e habilidades exigidas por esta nova relação com a informação e conhecimento, elevando o nível da capacidade do professor-usuário para saber relacionar, organizar e analisar situações de aprendizagem promovendo uma nova identidade de saber-fazer docente e ao mesmo tempo realizar o mesmo processo consigo. Por fim, analisaremos modos de aplicações das Tecnologias Educacionais que viabilize a troca de experiências, métodos de atividades e avaliações.

Consideramos este projeto inovador na medida em que a literatura sobre as Tecnologias Educacionais ainda insiste em formação continuada para professores em modelos de capacitação voltados para a tecnologia em si, enquanto não investem em posicionamentos pedagógicos inovadores que favoreçam o aparecimento irruptivo e invisível da tecnologia na sala de aula. $O$ posicionamento que adotamos acredita que é possível investir nos recursos humanos atuais, isto é, nos docentes imigrantes digitais, promovendo um movimento em direção positiva para as mudanças que o mundo tecnológico nos impõe e ao mesmo tempo em que evitamos demissões em massa, rotatividade de pessoal ou passividade perante as tecnologias enquanto se aguarda que os nativos digitais possam licenciar-se nas disciplinas escolares. Devemos recordar que a tecnologia deve auxiliar no processo natural de adaptação e mudança do ser humano, e, portanto, não está a serviço da segregação, exclusão ou padrão de competência.

Este modelo de formação continuada pretende amenizar a crise pela qual a escola passa diante da discrepância da sala de aula e a realidade do público diferenciado que se apresenta como nativos digitais. Desta forma pretendemos diminuir o número de evasão escolar por falta de interesse, melhorar a qualidade da aprendizagem e assim aumentar o nível de satisfação e rendimento dos alunos que passam a maior parte de seu dia no ambiente escolar. Ao mesmo tempo o público alvo, os professores da educação básica, terá a possibilidade de interrogar-se sobre suas próprias concepções pedagógicas, diminuindo seus esforços pela diversificação da tarefa docente e angariando maior qualidade no ensino mediante a mudança do seu idioma pedagógico. Isto quer dizer que o professor ganhará em qualidade de vida, trabalho e se atualizará para mais tempo de vida-útil em sua profissão.

Em 2010, o Sistema Firjan lançou o Programa Conectividade com o objetivo de incorporar as novas tecnologias ao processo educacional do SESI e SENAI. O programa se estrutura em quatro vertentes, conforme explicitado na figura abaixo:
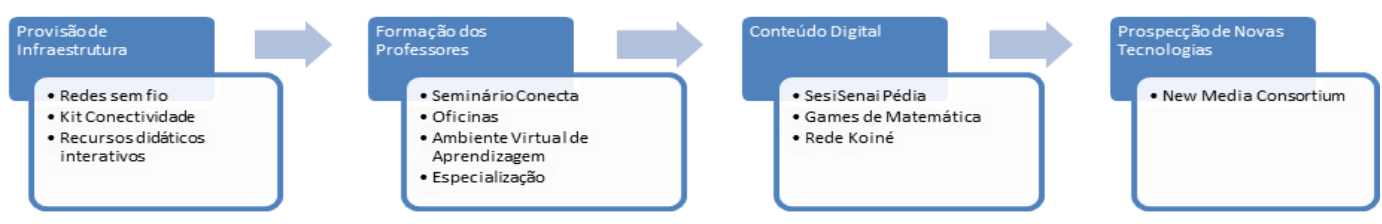

Figura 1: Vertentes do Programa Conectividade do Sistema Firjan. 
A experiência empírica proveniente do auxílio direto e cotidiano no exercício da função de Interlocutor de Tecnologias Educacionais, mais intenso durante a execução da vertente da formação de professores através das Oficinas de Tecnologias Educacionais, na escola SESI Cinelândia, iniciadas em fevereiro de 2012, tornou possível assinalarmos duas necessidades basilares destes docentes acerca dos usos das TIC's nos processos na sala de aula, ao quais passamos a delinear a seguir.

A primeira incide no Analfabetismo Digital de uma grande parcela dos professores. $O$ analfabetismo digital, ainda encontrado na nossa realidade, abrange desde o desconhecimento completo sobre o uso e funcionamento das tecnologias em si, isto é, quanto instrumento; estendendose ao uso das ferramentas da Web - e-mail, sites e intranet -, assim como os softwares básicos dos pacotes Office. E como segunda necessidade, a elaboração de um Novo Posicionamento Didático que possa tornar a tecnologia invisível, irruptiva e educacional àquele componente curricular específico, em detrimento do reducionismo ao uso como recurso em uma "aula especial" ou "diferente" eu apenas serve para reproduzir um modelo remoto de ensino com uso de instrumentos digitais. 


\section{Metodologia}

Neste projeto de formação continuada orientamos nossa estratégia para o problema principal, isto é, para a recuperação da competência do professor e não do aluno, que desta forma deixa de ser objeto de ensino e instrução, e torna-se parceiro de trabalho (DEMO, 2000). Nosso público-alvo são os professores da Escola SESI, imigrantes digitais, que necessitam saber aplicar as TIC's como Tecnologias Educacionais.

Destacamos o processo em duas etapas distintas ao qual pretende dar conta das duas necessidades identificadas na relação cotidiana e formativa dos professores, a saber, uma chamada de Formação Básica que contempla o uso das TIC's como objeto em si mesmo e a Formação Continuada em Tecnologias Educacionais que contemplará o desenvolvimento da nova linguagem didática pelo uso das TIC's.

\subsection{Formação Básica}

Imbuídos da necessidade de extinguir o analfabetismo digital do nosso corpo docente organizamos o curso de informática denominado Básico em TI para Professores. O curso, com carga horária total de 16 horas, abordará comandos básicos de usuários de microcomputador desktop e notebook's, com ênfase nas tecnologias disponibilizadas no Kit Conectividade do Sistema Firjan. Serão abordadas temáticas quanto ao uso prático do Sistema Operacional, Internet, Word e Power Point, em nível de usuário básico. Neste processo incluiremos principalmente aqueles que ainda se encontram fora do grupo dos imigrantes digital, e, portanto utilizam pouco ou nenhuma tecnologia. Este processo necessariamente é imersivo e inclusivo.

Para o curso Básico em TI para Professores separamos abaixo a tabela que indicam as habilidades, competências e carga horária a serem observadas. A Tabela 2 indicam as referências complementares que norteiam a construção conceitual desta primeira parte. 
Tabela 1: Planejamento das habilidades e competências do curso Básico em TI para Professores

\begin{tabular}{|c|c|c|c|}
\hline & Módulo 1 - Windows & Módulo 2 - Internet & $\begin{array}{c}\text { Módulo } 3 \text { - Power } \\
\text { Point }\end{array}$ \\
\hline $\begin{array}{l}\text { Habilidades } \\
\text { Técnicas }\end{array}$ & $\begin{array}{c}\text { Tornar-se usuário do } \\
\text { sistema operacional } \\
\text { Windows e conquistar } \\
\text { confiança no manuseio } \\
\text { dos recursos } \\
\text { tecnológicos } \\
\end{array}$ & $\begin{array}{l}\text { Tornar-se participante da } \\
\text { cultura digital por seus } \\
\text { meios de comunicação }\end{array}$ & $\begin{array}{l}\text { Desenvolver aulas com } \\
\text { mais recursos digitais a } \\
\text { fim de melhorar o } \\
\text { processo de ensino- } \\
\text { aprendizagem }\end{array}$ \\
\hline $\begin{array}{l}\text { Competências } \\
\text { Técnicas }\end{array}$ & $\begin{array}{l}\text { Dominar os processos } \\
\text { de Pastas e Subpastas; } \\
\text { utilização e acessos } \\
\text { aos discos fixos e } \\
\text { removíveis; copiar, } \\
\text { mover e renomear } \\
\text { arquivos; identificar e } \\
\text { manipular os tipos de } \\
\text { arquivos; utilizar as } \\
\text { funções da lixeira. }\end{array}$ & $\begin{array}{l}\text { Conhecer os conceitos de } \\
\text { Site, URL e Servidor; } \\
\text { dominar os tipos de } \\
\text { navegadores e seus } \\
\text { comandos básicos; } \\
\text { compreender e utilizar o } \\
\text { e-mail corporativo, os } \\
\text { comandos básicos e } \\
\text { anexar arquivos; } \\
\text { download; } \\
\text { compactadores de } \\
\text { arquivos; antivírus e o } \\
\text { conceito de spam. } \\
\end{array}$ & $\begin{array}{c}\text { Saber desenvolver e } \\
\text { planejar aulas } \\
\text { expositivas neste } \\
\text { ambiente. }\end{array}$ \\
\hline Carga Horária & 8 horas & 5 horas & 3 horas \\
\hline
\end{tabular}

Tabela 2: Referências complementares do curso de Formação Básica em TI Básico para professores

\begin{tabular}{|l|l|}
\hline Público Alvo & $\begin{array}{l}\text { Professores do Ensino Médio e Ensino Fundamental (Regular e EJA) } \\
\text { que se reconheçam no analfabetismo digital e/ou aqueles apontados } \\
\text { pela direção escolar. }\end{array}$ \\
\hline Objetivo & $\begin{array}{l}\text { Possibilitar a aproximação dos professores aos recursos digitais; } \\
\text { instruir aos usuários quando a realidade da construção de uso pelo } \\
\text { método "tentativa-erro", possibilitando diminuir o medo de utilizar os } \\
\text { novos dispositivos tecnológicos de modo geral; iniciar aos usuários } \\
\text { nos serviços básicos de TI necessários ao bom funcionamento da } \\
\text { escola, às exigências da empresa e da modernidade. }\end{array}$ \\
\hline Carga Horária & 16h \\
\hline Pressuposto Teórico & Educar pela Pesquisa (DEMO, 2000) \\
\hline Encontros & Duas vezes por semana. Duas horas por encontro. \\
\hline Habilidades & Saber utilizar os dispositivos disponibilizados no Kit Conectividade \\
\hline Competência & $\begin{array}{l}\text { Realizar tarefas de usuário, nível básico, dos recursos dos } \\
\text { computadores e da internet. }\end{array}$ \\
\hline Competência Técnica & $\begin{array}{l}\text { Utilização do Sistema Operacional Windows 7, Pacote Office básico, } \\
\text { pesquisar no ambiente WEB e enviar e-mail. }\end{array}$ \\
\hline Habilidades Técnicas & $\begin{array}{l}\text { Conectar o notebook ao kit multimídia, utilizar o e-mail corporativo, } \\
\text { criar pequenos textos e apresentações. }\end{array}$ \\
\hline
\end{tabular}

O Segundo Módulo, denominado Pesquisa Básico em TI, acontece em cinco semanas e ocorrerá juntamente com o Módulo 3 da Formação Continuada em Tecnologias Educacionais, 
objetivando promover a todos os participantes um espaço de conhecimento em rede, para trocar informações, consolidar os conhecimentos adquiridos no curso Básico TI para Professores, promover a possibilidade de se adaptarem juntos ao sistema AVA- MOODLE e dirimir as dúvidas, bem como realizarem em conjunto as tarefas propostas e compartilharem experiências sobre as leituras dirigidas.

\subsection{Formação Continuada em Tecnologias Educacionais}

Para melhor determinar a demanda da segunda necessidade elaboramos uma pesquisa ${ }^{4}$, restrita aos 143 professores da Unidade Cinelândia. Trata-se de um questionário fechado, no modelo de resposta ao item, aos quais, dentro da amostra dos arguidos, retificaram as seguintes questões: $100 \%$ acreditam que as inclusões das Tecnologias favorecem a Educação; $60 \%$ dos docentes não estudaram em sua formação inicial sobre as Tecnologias Educacionais aplicadas à sala de aula e mais $24 \%$, deste mesmo item, afirmaram ter estudado, mas que não se sentiram preparados para a implementação; $76 \%$ dos respondentes não se sentiam preparados para utilizarem as Tecnologias Educacionais antes das Oficinas; e, 97\% acreditam que a utilização das Tecnologias Educacionais exige nova postura didática.

Segue, em forma gráfica, o resultado dos itens mais importantes para esta pesquisa:

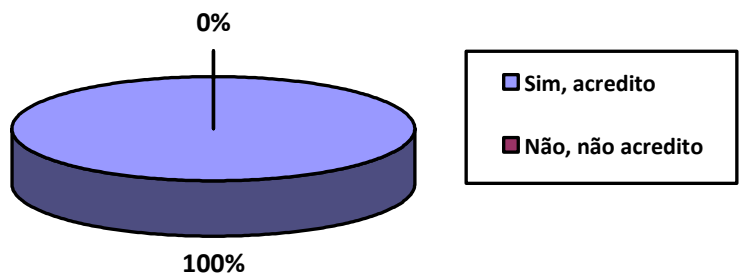

Figura 2: Você acredita que a inclusão das Tecnologias da Informação e Comunicação (TIC's) favorecem a Educação?

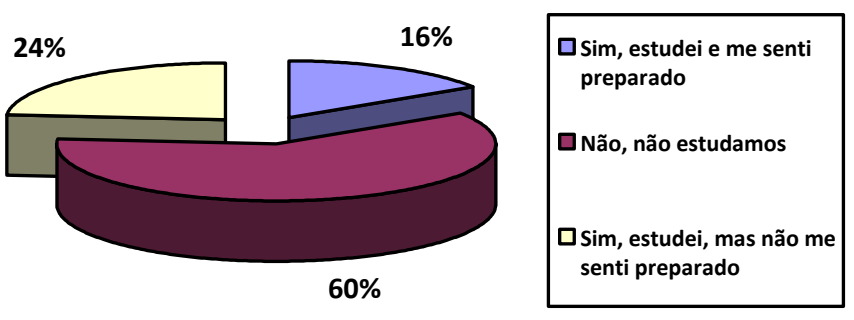

Figura 3: Na sua formação inicial você estudou sobre Tecnologias Educacionais?

\footnotetext{
${ }^{4}$ Anexo A - Pesquisa aos Docentes sobre as Tecnologias Educacionais na Unidade Cinelândia.
} 


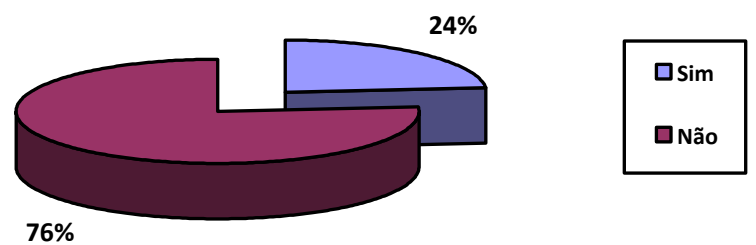

Figura 4: Antes das Oficinas de Tecnologias Educacionais oferecidas pelo SESI você se sentia preparado(a) para utilizar as TIC's na sala de aula?
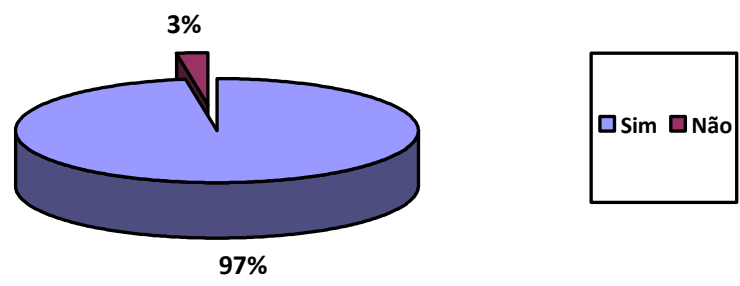

Figura 5: Você acredita que seja necessário uma NOVA postura didática para a utilização das Tecnologias Educacionais na sala de aula?

Alicerçados pelos dados obtidos da pesquisa podemos concluir que: as Tecnologias Educacionais melhoram o desempenho do ensino-aprendizagem e que a convicção dos docentes nesta afirmativa colaborará para melhores resultados no programa de formação continuada que propomos nesta pesquisa; que existe uma deficiência na formação inicial sobre aplicação das TIC's na sala de aula e que se faz necessário o surgimento de um novo fazer pedagógico com nova postura didática.

Entendemos por nova postura didática ou novo fazer pedagógico, a aplicação de uma regência, ainda em construção, que possa atender as demandas do mundo tecnológico e globalizado, desta sociedade do compartilhamento, do conhecimento, da informação e da inovação. Esta nova demanda surge a partir da sociedade de pessoas conectadas e que por isso não participam da realidade de uma possível transmissão do saber qualificado pela capacidade de reter conhecimento, mas ao contrário inaugura-se uma nova lógica do saber sendo igual a acessar o conhecimento construído pela lógica globalizada do compartilhamento.

Uma nova atitude no processo de ensinar e aprender requer sair da imitação da didática na qual o professor é aquele que retém o conhecimento e inaugurar um processo de ensinar a aprender centrado no aluno para promover a autonomia da busca do conhecimento. Assim como a exigência aponta para uma mudança profunda da postura didática do professor, o processo de mudança requer que o docente abandone qualquer imitação dos antigos processos, sendo convocado desta forma a alterar, necessariamente, os modos, os objetos e os meios de sua prática profissional (ARISTÓTELES, 2004, p.39). 
$\mathrm{Na}$ segunda parte da Formação Continuada pretendemos atingir esta nova linguagem didática, no desenvolvimento de quatro módulos, afeiçoando-se e conectando os modelos propostos por Lelis (2001; 2008), Campos et all (2007), Martins e Giraffa (2008).

Tabela 3: Planejamento das Habilidades e Competências da Formação Continuada em Tecnologias Educacionais

\begin{tabular}{|c|c|c|c|c|}
\hline & Módulo 1 & Módulo 2 & Módulo 3 & Módulo 4 \\
\hline $\begin{array}{l}\text { Habilidade } \\
\text { Pedagógica }\end{array}$ & $\begin{array}{l}\text { Saber Situar e } \\
\text { saber Situar-se }\end{array}$ & $\begin{array}{c}\text { Saber Relacionar e } \\
\text { Saber Relacionar- } \\
\text { se }\end{array}$ & $\begin{array}{c}\text { Saber Organizar e } \\
\text { Saber Organizar- } \\
\text { se }\end{array}$ & $\begin{array}{c}\text { Saber Analisar e } \\
\text { Saber Analisar- } \\
\text { se }\end{array}$ \\
\hline $\begin{array}{l}\text { Competência } \\
\text { Pedagógica }\end{array}$ & $\begin{array}{l}\text { Compreensão da } \\
\text { Sociedade do } \\
\text { Conhecimento, } \\
\text { Cultura Digital e } \\
\text { Interatividade } \\
\text { como modo de } \\
\text { gerir } \\
\text { conhecimento. }\end{array}$ & $\begin{array}{l}\text { Uso, Gestão e } \\
\text { Integração das } \\
\text { Mídias no fazer } \\
\text { pedagógico }\end{array}$ & $\begin{array}{l}\text { Planejamento de } \\
\text { Desing Didático } \\
\text { como uma forma } \\
\text { de abrangência à } \\
\text { relação } \\
\text { pedagógica, } \\
\text { social. }\end{array}$ & $\begin{array}{c}\text { Desenvolver } \\
\text { projetos } \\
\text { pedagógicos que } \\
\text { utilizem } \\
\text { Ferramentas da } \\
\text { Web } 2.0 \text { capazes } \\
\text { de construir } \\
\text { aprendizagens e } \\
\text { avaliações. }\end{array}$ \\
\hline Objetivo & $\begin{array}{c}\text { Conhecer as } \\
\text { competências e os } \\
\text { saberes que são } \\
\text { imprescindíveis ao } \\
\text { professor } \\
\text { contemporâneo } \\
\text { para construir e } \\
\text { desconstruir } \\
\text { modelos de } \\
\text { ensino para a } \\
\text { modernidade. }\end{array}$ & $\begin{array}{l}\text { "Construir uma } \\
\text { identidade } \\
\text { profissional que } \\
\text { valorize o professor } \\
\text { como animador de } \\
\text { redes de } \\
\text { aprendizagem" } \\
\text { (LELIS, 2008, p. } \\
61)\end{array}$ & $\begin{array}{c}\text { "Promover } \\
\text { espaços de } \\
\text { aprendizagem } \\
\text { inter-pares, de } \\
\text { inscrever os } \\
\text { princípios } \\
\text { coletivos na } \\
\text { cultura profissional } \\
\text { dos professores" } \\
\text { (LELIS, 2008, p. } \\
61 \text { ) }\end{array}$ & $\begin{array}{c}\text { Ensinar a } \\
\text { aprender e } \\
\text { aprender a } \\
\text { ensinar com a } \\
\text { experiência. } \\
\text { Elaborar, discutir, } \\
\text { argumentar, } \\
\text { fazer propostas } \\
\text { para formular } \\
\text { projetos } \\
\text { pedagógicos } \\
\text { próprios e } \\
\text { inovadores. }\end{array}$ \\
\hline $\begin{array}{l}\text { Dimensão } \\
\text { do Novo } \\
\text { Processo } \\
\text { Didático }\end{array}$ & Objeto & Meios & Modo & Avaliação \\
\hline $\begin{array}{l}\text { Carga } \\
\text { Horária }\end{array}$ & 15 horas & 25 horas & 20 horas & 20 horas \\
\hline
\end{tabular}

Tabela 4: Referências complementares da Formação Continuada em Tecnologias Educacionais

\begin{tabular}{|l|l|}
\hline Público Alvo & $\begin{array}{l}\text { Todos os Professores do Ensino Médio e Ensino Fundamental } \\
\text { (Regular e EJA) }\end{array}$ \\
\hline Carga Horária & $80 \mathrm{~h}$ \\
\hline Pressuposto Teórico & Educar pela Pesquisa (DEMO, 2000) \\
\hline Encontros & $\begin{array}{l}\text { Método on-line pelo AVA com três encontros presenciais } \\
\text { conforme apontado no cronograma. }\end{array}$ \\
\hline
\end{tabular}




\begin{tabular}{|l|l|}
\hline Habilidades Pedagógicas & $\begin{array}{l}\text { Saber Situar, Relacionar, Organizar e Analisar ante as TIC's } \\
\text { aplicadas ao processo Educacional }\end{array}$ \\
\hline Competência Pedagógica & $\begin{array}{l}\text { Compreender o aluno inserido na própria cultura e a partir disso } \\
\text { fazer uso de ferramentas da WEB 2.0 por meio da integração } \\
\text { das mídias e de novos planejamentos didáticos para } \\
\text { aprendizagem e avaliação. }\end{array}$ \\
\hline Competência Técnica & Utilização das TIC's \\
\hline Habilidades Técnicas & $\begin{array}{l}\text { Utilizar o MOODLE como gerenciador de aprendizagem; } \\
\text { editores de textos; gerenciador de e-mails; uso de ferramentas } \\
\text { de busca download e upload de arquivos. }\end{array}$ \\
\hline
\end{tabular}

Seria contraditório caso o formato da Formação Continuada não contemplasse períodos de estudos em AVA (Ambiente Virtual de Aprendizagem), neste caso nos servirá o MOODLE 5 , pois o próprio professor necessita da experiência de aquisição e compartilhamento do conhecimento por meio da exploração, do hipertexto e do uso do ciberespaço, não só na forma alternativa ou complementar, mas ambiente para construção do conhecimento. Esta experiência possibilitará a imersão do processo de aprendizagem típica dos nativos digitais que ocorrem em meio de repletos de recursos estimulantes da WEB 2.0 e diversos motivos para distrações.

Em contrapartida, faz-se necessário que os mediadores estejam aptos a mediar situações de sentimento de "não-aprender" de alguns imigrantes digitais, que movidos pela necessidade de acumular objetos materiais e realizar registros físicos, podem apresentar sinais de angústia por meio de desânimo, críticas sem fundamentos ou isolamento.

A metodologia adotada em ambos os períodos da formação continuada é baseada na concepção descrita no livro Educar pela Pesquisa, de Pedro Demo (2000). Todos os espaços sociais e agentes educam, porém, utilizam de outro expediente que não a pesquisa, base da educação escolar, que orientará nossos processos.

Escolhemos este método por entender que as TIC's já oferecem à sociedade moderna a capacidade de acesso e desenvolvimento do conhecimento. Cabe neste momento à educação, ao fazer uso desta capacidade contemporânea, permitir ao aluno uma aprendizagem pelo questionamento (re)construtivo que faculta ao sujeito aprendiz o acesso à qualidade formal e política, inovação e intervenção.

Segundo Pedro Demo (2000) está na concepção de Educar pela Pesquisa um caminho para sairmos da condição de objeto (massa de manobra), pois na educação pelo questionamento reconstrutivo, efeito de educar pela pesquisa, o surgimento da capacidade de construímos características emancipatórias. Dentre as particularidades desta forma de ensinar possibilitamos a passagem de nos colocar contra a ignorância para agir na base do saber pensar; valorizamos 0 questionamento, marca inicial do sujeito histórico; dedicamos ao processo reconstrutivo, aumentando às competências e a inovação; facultamos a confluência entre teoria e prática para construir uma

\footnotetext{
${ }^{5}$ É um software livre, de apoio à aprendizagem, executado num ambiente virtual. Utilizado principalmente num contexto de e-learning, o programa permite a criação de cursos "on-line", páginas de disciplinas, grupos de trabalho e comunidades de aprendizagem. Atualmente é a ferramenta mais utilizada no nível superior em todo o país.
} 
realidade concreta; passamos a nos opor à condição de objeto e aos procedimentos manipulativos, porque negam o sujeito e condenamos a cópia do ensino copiado, porque esta consagra a subalternidade.

Por fim, uma condição especial para se educar pela pesquisa por meio das TIC's é compreender que o profissional da educação seja usuário, mesmo básico, e um pesquisador, não como um princípio científico e educativo, mas como uma atitude cotidiana (ib, 2000). Ninguém educa pela pesquisa se não aprende pela pesquisa. Sendo assim, mais do que nunca, a metodologia que embasa este processo prevê que não sejam aplicadas aulas aos quais se repassam, transmitem ou socializam conhecimentos, mas oferecer aos professores/alunos a oportunidade de experimentarem, talvez pela primeira vez, outro modo de aprender e formar a autonomia crítica e criativa; sujeito do processo, e não objeto; a individualidade mantendo a solidariedade enquanto se procura materiais e fomenta a inciativa pela interpretação própria. 


\section{Estratégia de Ação}

Toda ação proposta está composta de duas partes distintas, a primeira referente à Formação Básica em tecnologias da informação e comunicação para professores imigrantes digitais que ainda não dominam os recursos básicos das ferramentas e por isso percebem o fato como um empecilho que os torne incapazes de aplicá-las como Tecnologias Educacionais.

A segunda parte aborda a Formação Continuada em Tecnologias Educacionais, uma formação pedagógica e prática que capacite e municie os professores a utilizar as TIC's em seu cotidiano docente e desta forma favoreça o alvorecer de uma nova postura didática para os novos tempos.

\subsection{Formação Básica}

A Formação Básica possui dois módulos, o curso (1) Básico em TI para Professores e (2) Pesquisa Básico em TI, conforme a figura abaixo:

\section{Formação Continuada para Imigrantes Digitais}

\section{Formação Básica}
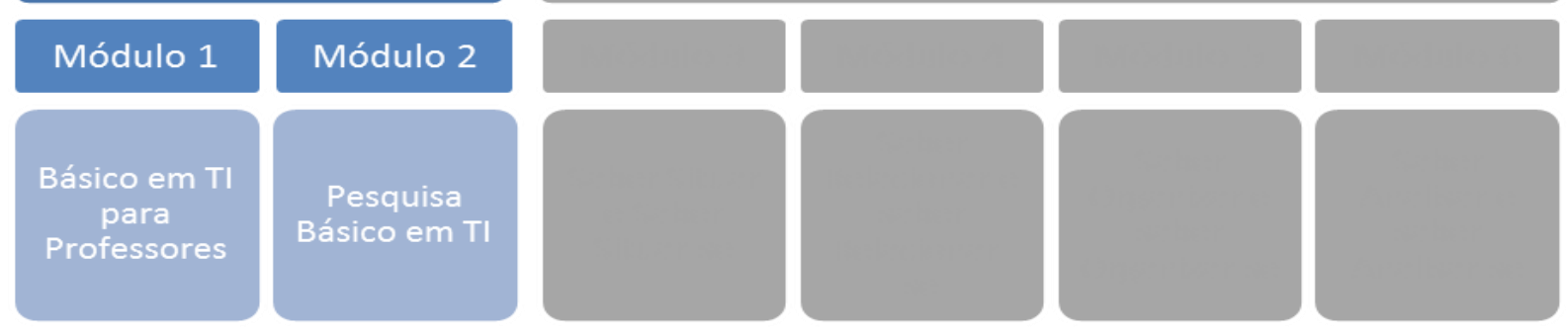

Figura 6: Estrutura da formação continuada - ênfase na formação básica

O primeiro módulo não se estende a todo o corpo docente, mas aos professores que expressarem sua identificação com o grupo dos que desconhecem totalmente os processos básicos das TIC's e/ou aqueles que a Direção Escolar apontar como desprovidos dos conhecimentos básicos, e por isso expondo deficiências no cotidiano escolar para que possam ser solucionadas através do desenvolvimento das habilidades e competências propostas (Tabela 1).

A tabela abaixo descreve os recursos humanos e materiais necessários para a execução desta etapa:

Tabela 5: Recursos Humanos e Materiais para o curso Básico em TI para Professores

\begin{tabular}{|c|c|l|}
\hline Natureza & Descrição & \multicolumn{1}{|c|}{ Origem } \\
\hline Recurso Material & Laptop & $\begin{array}{l}\text { Cada docente fará uso do seu material, } \\
\text { objetivando terminar com a noção de laboratório }\end{array}$ \\
\hline
\end{tabular}




\begin{tabular}{|l|l|l|}
\hline & & $\begin{array}{l}\text { de informática e produzindo conhecimento em seu } \\
\text { próprio material pessoal. Imprescindível que o } \\
\text { curso seja realizado na proporção de 1 laptop por } \\
\text { pessoa. }\end{array}$ \\
\hline Recurso Material & Desktop & $\begin{array}{l}\text { Este computador será utilizado pelo facilitador } \\
\text { desta oficina. }\end{array}$ \\
\hline Recurso Material & $\begin{array}{c}\text { Projetor Multimídia } \\
\text { (Datashow) }\end{array}$ & $\begin{array}{l}\text { Este material será usado para exibir aos alunos o } \\
\text { modo de fazer os comandos utilizados no curso. }\end{array}$ \\
\hline Recurso Material & $\begin{array}{c}\text { Internet Banda Larga } \\
\text { Wi-fi }\end{array}$ & Será utilizado para as aulas de Internet e E-mail. \\
\hline Recurso Humano & Facilitador & $\begin{array}{l}\text { Preferência para docente do mesmo nível de } \\
\text { atuação dos professores que os cursistas. Desta } \\
\text { forma se garante a linguagem e os exemplos } \\
\text { próprios. }\end{array}$ \\
\hline
\end{tabular}

Sabendo que os cursistas ainda não perpetraram a transição do modelo de ensino clássico para a nova linguagem didática atravessada pelo uso das TIC's, poderão apresentar dificuldades na assimilação do conteúdo caso esta etapa funcione além do que estão acostumados. Assim propomos o modelo de ensino utilizado pela rede de escola de informática Cedaspy ${ }^{6}$, chamado E.D.A.A., que consiste na Explanação, Demonstração, Aplicação e Acompanhamento.

Neste modelo, a primeira etapa é a Explanação, momento em que se define o que fazer. Esta etapa ocorre nos primeiros momentos de cada tópico, detalha sua importância e aplicação prática. Em seguida temos a Demonstração que é a execução de uma tarefa com conteúdos significativos elaborados a partir do que foi explanado; utiliza-se neste momento o projetor e os cursistas apenas observam o desenvolvimento. A aplicação sucede-se imediatamente como consequência das duas partes anteriores e comumente o aluno repete os movimentos do facilitador. Por fim na etapa do Acompanhamento, o discente recebe um desafio, atividade formalizada a partir de experiências docentes e escolares, ao qual é convocado a aplicar o que aprendeu enquanto é mediado pelo facilitador.

O módulo Básico em TI para Professores preferencialmente acontecerá duas vezes por semana, com duas horas de duração, pois o tempo para a acomodação das informações e de exposição às tecnologias são fatores essenciais no aprendizado de seu uso e conhecimento de suas potencialidades. O prazo desta etapa são quatro semanas.

No segundo módulo, Pesquisa Básico em TI, não existirão aulas expositivas e sim um arranjo inicial do que seriam as comunidades de aprendizagem. Mantem-se os mesmo recursos humanos e tecnológicos do Módulo 1 (tabela 5). Nesta etapa os participantes do primeiro módulo continuarão a frequentar e os outros docentes poderão participar desde que tragam seu próprio material. Não estimamos o número máximo de cursistas nos encontros, pois seguindo o modelo de

\footnotetext{
${ }^{6}$ Disponível no link: http://www.cedaspy.com.br/?pg=institucional\&institucional_id=16
} 
comunidades de aprendizagem, o processo de aprendizagem não se concentra no facilitador, mas na pesquisa do aluno e no auxílio dos colegas.

Os objetivos desta etapa são: oferecer um espaço para retenção dos comandos aprendidos no primeiro módulo; possibilitar o contato do cursista com a tecnologia de modo a contar com o suporte dos colegas e do facilitador que mediarão à busca pelas soluções; garantir um ambiente que possa gerar novas demandas de aprendizagem e resolver questões tecnológicas de ordem prática e burocrática do cotidiano escolar que requerem o uso exclusivo das TIC's; por fim, servir de suporte às dúvidas das atividades proposta no Ambiente Virtual de Aprendizagem, o MOODLE, pois o Módulo 3 , propositalmente, tem início ao mesmo tempo que a Formação Continuada em Tecnologias Educacionais.

\subsection{Formação Continuada em Tecnologias Educacionais}

A Formação Continuada em Tecnologias Educacionais está disposta em quatro módulos, com contagem seguindo a sequência da primeira parte, conforme a figura abaixo:

\section{Formação Continuada para Imigrantes Digitais}
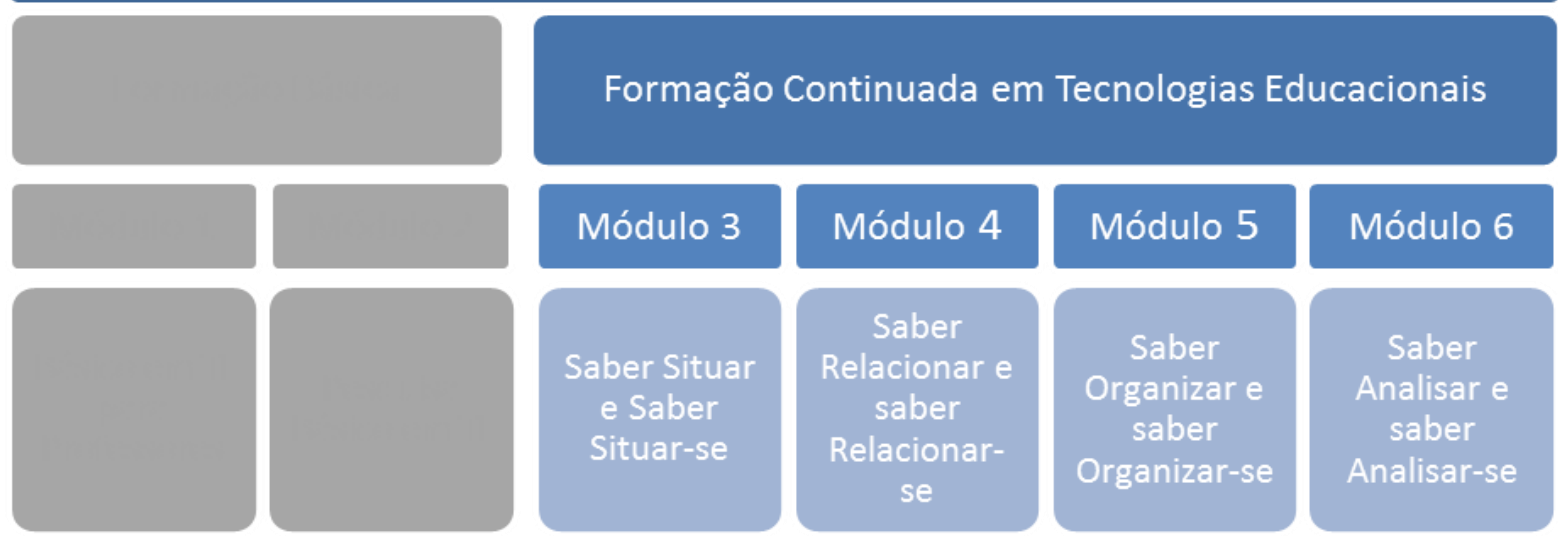
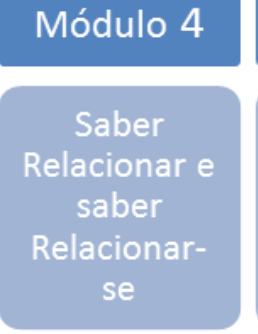

Módulo 5

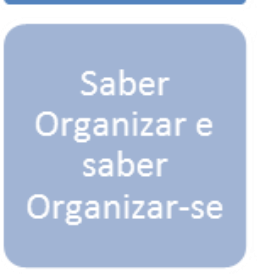

Módulo 6

Saber

Analisar e

saber

Analisar-se

Figura 7: Estrutura da formação continuada - ênfase na Formação Continuada em Tecnologias Educacionais

A tabela abaixo descreve os recursos humanos e materiais necessários para a execução desta etapa, lembrando a especificidade da disponibilidade nos dias conforme o cronograma.

Tabela 6: Recursos Humanos e Materiais para a Formação em Tecnologias Educacionais

\begin{tabular}{|c|c|l|}
\hline Natureza & Descrição & \multicolumn{1}{c|}{ Origem } \\
\hline Recurso Material & Laptop & $\begin{array}{l}\text { Cada docente fará uso do seu material e com a } \\
\text { liberdade de realizar os seus estudos em qualquer } \\
\text { espaço físico, conforme a liberdade da EAD. }\end{array}$ \\
\hline
\end{tabular}




\begin{tabular}{|l|c|l|}
\hline Recurso Material & Desktop & $\begin{array}{l}\text { Este computador será utilizado pelos cursistas nos } \\
\text { encontros presenciais. }\end{array}$ \\
\hline Recurso Material & $\begin{array}{c}\text { Projetor Multimídia } \\
\text { (Datashow) }\end{array}$ & $\begin{array}{l}\text { Este material será usado para pelos cursistas nos } \\
\text { encontros presenciais para exibirem seus Projetos } \\
\text { Educacionais. }\end{array}$ \\
\hline Recurso Material & $\begin{array}{c}\text { Internet Banda Larga } \\
\text { Wi-fi }\end{array}$ & $\begin{array}{l}\text { Para acesso ao AVA e materiais colocados em } \\
\text { nuvem durante os encontros presenciais. }\end{array}$ \\
\hline Recurso Material & AVA - MOODLE & $\begin{array}{l}\text { Plataforma cedida gentilmente e gratuitamente } \\
\text { pelo Instituto de Saúde Mental e do do dink } \\
\text { Comportamento pelo } \\
\text { http://www.diogobonioli.com/salavirtual i d }\end{array}$ \\
\hline
\end{tabular}

Passamos a apresentar o objetivo, reflexões, tópicos e referências bibliográficas que formam o material orientador:

\section{Módulo 3}

Objetivo: refletir os espaços de interação e convívio que homem é capaz de criar e, desta forma, entendermos o conceito de cultura e seus desdobramentos através das instituições sociais como a família, escola, trabalho. De modo especial estenderemos este pensamento ao conceito de cultura digital como uma forma moderna de estar no mundo, de que forma as redes de comunicação se estabelecem e influencia o mundo, o papel da internet e, oportunamente, conjecturar esta nova linguagem com suas exigências de interatividade. A partir deste panorama pretendemos analisar todas estas influências e impactos sobre a educação, visto ser impossível separar a educação da concepção de cultura(s).

Novo processo didático: abordaremos neste módulo o conceito de OBJETO. Na medida em que o sujeito se posiciona na cultura digital, na nova linguagem e na interatividade em rede recebe-se uma convocação para refletir sobre quem seria de fato o objeto da educação, caso ele exista.

Tópicos: Cultura Digital e Educação; Redes de Comunicação e Interatividade; Internet: interação, construção e transmissão de conhecimento; Linguagem, gênero e roteiros interativos.

\section{Textos:}

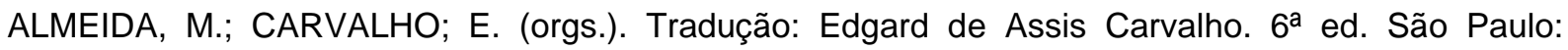
Cortez, 2013.

GUILE, D. O que distingue a economia do conhecimento? Implicações para a educação. Tradução: Inês Teixeira Barrancos. Cadernos de Pesquisa. v.38. n. 135, p. 611-636, set./dez. 2008

MORIN, E. Educação e complexidade: os sete saberes e outros ensaios.

SALTO PARA O FUTURO. Cultura Digital e Escola. Ano XX. Boletim 10. Rio de Janeiro. Agosto, 2010. Disponível em: http://www.tvbrasil.org.br/fotos/salto/series/13431810-Culturadigitaleescola.pdf SAVAZONI, R.; COHN, S. (org). Culturadigital.br. Rio de Janeiro: Beco do Azougue, 2009. 
Módulo 4

Objetivo: Não basta saber onde e como estamos, mas saber estabelecer relações é imprescindível em todos os processos humanos. Neste módulo refletiremos sobre os sistemas de comunicações da modernidade, com isso entendermos o conceito de mídias ao analisar sua mudança com o passar do tempo, sua influência na cultura, a influência da cultura sobre a elaboração da mídia, suas características atuais e impactos sobre os usuários. Por fim analisaremos a confluência das linguagens na criação das mídias e como estas podem ser determinantes na nova linguagem didática que permeará novas concepções acerca do processo de ensino-aprendizagem.

Novo processo didático: abordaremos neste tópico o conceito de MEIOS. A mídia é um meio, a mídia digital uma compulsão moderna. Inovação no ensino também requer novidade nas mídias e da mesma forma que a concepção tradicional já está ultrapassada para esta época, igualmente são suas mídias. O grande esforço que se faz é não utilizar novas mídias para realizar o modo que seria feito com as antigas.

Tópicos: Sistemas de Comunicação e Mídias; Integração de Linguagens pelas Mídias.

FALCÃO, B. A narrativa transmídia como instrumento de mediação pedagógica: o papel do professor no contexto das novas tecnologias. 31/05/2011. Disponível em: http://professorabarbarafalcao.wordpress.com/2011/05/31/a-narrativa-transmidia-como-instrumentode-mediacao-pedagogica-o-papel-do-professor-no-contexto-das-novas-tecnologias/

GOSCIOLA, V.; VERSITI, A. Narrativa transmídia e sua potencialidade na educação aberta. In: Okada, A. (ed.) Open Educational Resources and Social Networks: Co-Learnin na Professional Development. London: Scholio Educational Research \& Publishing, 2012. Disponível em: http://oer.kmi.open.ac.uk/?page_id=428

\section{Módulo 5:}

Objetivo: $O$ uso das TIC's na sala de aula acende no imigrante digital uma necessidade especial de planejamento didático provocado pela imposição das mídias digitais e pela postura de ação de educar pela pesquisa ao exigir o surgimento desta nova linguagem didática ao qual aprenderemos a conceituar de Design Instrucional ou Engenharia Pedagógica. Neste módulo temos como objetivo desenvolver uma nova didática que favoreça a inserção das mídias, um ambiente de aprendizagem colaborativa e o uso de recursos educacionais relacionados com as TIC's. Ainda neste módulo refletiremos sobre o uso de imagens, sons, rádio, TV e outros objetos educacionais aplicados ao processo didático.

Novo processo didático: Neste módulo apresentamos a oportunidade de exercitar a prática que transforma os objetos da TIC's em Tecnologias Educacionais. Sendo assim é imprescindível saber organizar e organizar-se para alterar o conceito de MODO dentro da prática didática. 
Tópicos: Design Instrucional; Recursos Educacionais e Planejamento Pedagógico.

FARBIARZ, J.; FARBIARZ, A.; XAVIER, G. Uma abordagem dialógica do Desing Instrucional. VII Congresso Brasileiro de Pesquisa e Desenvolvimento em Design. Disponível em: http://www.dad.pucrio.br/nel/artigos/06-farbiarz-ped.pdf. Acessado em 12/12/2013.

NEVES, $M$ et all. Design educacional construtivista: o papel do desing como planejamento na educação a distância. SIED 2012 \& EnPED 2012. Universidade de São Carlos - UFSCar. 10 a 12 de setembro de 2012. Disponível em: http://sistemas3.sead.ufscar.br/ojs/Trabalhos/145-932-1-ED.pdf. Acessado em 12/12/2013

\section{Módulo 6:}

Objetivo: O último módulo destina-se a analisar quais ferramentas a WEB 2.0 pode oferecer como Tecnologia Educacional e como aplicá-las de modo a serem mais eficazes no processo de aprendizagem. Por fim, analisaremos os conceitos de Avaliação Qualitativa, de Pedro Demo e Avaliação Mediadora, de Jussara Hoffmann, a fim de que possamos pensar o conceito de avaliação diferenciada, perpassada pelas ferramentas da WEB 2.0 e que possam ser inseridas no contexto das TIC's.

Novo processo didático: $O$ conceito a ser (re)construído é AVALIAÇÃO a partir do próprio saber analisar-se, analisar o instrumento e, por fim, o aluno.

Tópicos: Ferramentas da WEB 2.0, Avaliação Qualitativa; Avaliação Mediadora.

DEMO, Pedro. Avaliação qualitativa. 8.ed. Campinas: Autores Associados, 2005.

CARVALHO, A. Manual de ferramentas da WEB 2.0 para professores. Ministério da Educação DGIDC, 2008. Disponível em: http://www.crie.min-edu.pt/publico/web20/manual_web20professores.pdf. Acessado em 12/12/2013

HOFFMANN, J. Avaliação Mediadora - Uma prática em construção da pré-escola à universidade. $32^{\text {a }}$ Edição atual e revista. Porto Alegre: Mediação, 2009.

VANDRESSEN, A. WEB 2.0 e educação - usos e possibilidades. X Congresso Nacional de Educação - EDUCERE. PUCPR. Curitiba, 7 a 10 de novembro de 2011. Disponível em: http://educere.bruc.com.br/CD2011/pdf/5752_3325.pdf. Acessado em 12/12/2013.

\subsection{Encontros Presenciais}

\section{Primeiro Encontro Presencial}


Tema: Tecnologias, Sociedade e Cultura Digital

\section{Objetivos:}

1. Finalizar o Módulo 1 - Básico em TI para Professores;

2. Disponibilizar e instruir sobre o funcionamento do Módulo 2 destacando o arranjo em comunidades de aprendizagem;

3. Apresentar o conceito de Sociedade de Conhecimento, a nova economia tecnológica e do saber, e, por fim, o conceito de cultura digital;

4. Apresentar a organização e o cronograma da Formação Continuada para Professores Imigrantes Digitais;

5. Pontuar a Metodologia Educar pela Pesquisa que será aplicada durante a Formação Continuada, os Conceitos dos Módulos e os Novo Processo Didático.

6. Orientar sobre os Projetos Educacionais, como atividades práticas que serão desenvolvidas a partir das teorias estudadas no Módulo respectivo e apresentadas nos dois encontros presenciais posteriores;

7. Expor os recursos, acessos e possibilidades da plataforma MOODLE;

\section{Segundo Encontro Presencial}

Tema: Saber Situar, Relacionar e Organizar: Desing Instrucional

\section{Objetivos:}

1. Exposição dos Projetos Educacionais elaborados nos Módulos 3, 4 e 5.

2. Oferecer um espaço de comunicação de dúvidas e experiências;

3. Apresentar feedback resultado do monitoramento da plataforma MOODLE

\section{Terceiro Encontro Presencial}

Tema: Saber Analisar e Avaliar na Cultura Moderna Digital

\section{Objetivos:}

1. Exposição dos Projetos Educacionais elaborados no Módulo 6;

2. Oferecer um espaço de comunicação de dúvidas e experiências;

3. Apresentar feedback resultado do monitoramento da plataforma MOODLE;

4. Avaliação Final do curso de Formação Continuada para Professores Imigrantes Digitais; 


\section{Cronograma}

O projeto de Formação Continuada para Professores Imigrantes Digitais tem a duração de 20 semanas, aproximadamente cinco meses e com carga horária total de 96 horas. Este modelo foi escolhido para ajustar-se ao calendário de capacitação que comumente as instituições escolares realizam para regresso das aulas em fevereiro e agosto.

A primeira etapa, chamada de Formação Básica, possui a duração de nove semanas, sendo quatro semanas para o Módulo 1, e mais cinco semanas para o Módulo 2. Ambas somam nove semanas.

A segunda etapa, chamada de Formação Continuada em Tecnologias Educacionais contabilizam 15 semanas na modalidade de ensino à distância e três encontros presenciais previamente estabelecidos. A carga horária deste ciclo soma 80 horas, divididas em quatro módulos, estruturados de acordo com conhecimentos teóricos, saberes e processos a serem desenvolvidos. 


\begin{tabular}{|c|c|c|c|c|c|c|c|c|c|c|c|c|c|c|c|c|c|c|c|}
\hline Etapas & \multicolumn{19}{|c|}{ Tempo em Semanas } \\
\hline & 2 & 3 & 4 & 5 & 6 & 7 & $\overline{8}$ & 9 & 10 & 11 & 12 & 13 & 14 & 15 & 16 & 17 & 18 & 19 & 20 \\
\hline Fomacão Básica & & & & & & & & & & & & & & & & & & & \\
\hline Módulo 1: Básico em TI para Professores & & & & & & & & & & & & & & & & & & & \\
\hline Módulo 2: Pesquisa Básico em TI & & & & & & & & & & & & & & & & & & & \\
\hline
\end{tabular}

Formação Continuada em Tecnologias Educacionais Módulo 3: Saber Situar e Saber Situar-se

Cultura Digital e Educação

Redes de Comunicação e Interatividade

Internet: Interação, Construção e Transmissão do Conhecimento

Linguagem, Gênero e Roteiros Interativos

Novo Processo Didático: Objeto

Projeto Educacional

Módulo 4: Saber Relacionar e Saber Relacionar-se

Sistemas de Comunicação e Midias

Integração de Linguagens pelas Mídias

Novo Processo Didático: Meios

Projeto Educacional

Módulo 5: Saber Organizar e Saber Organizar-se

Desing Instrucional

Recursos Educacionais e Planejamento Pedagógico

Novo Processo Didático: Modo

Projeto Educacional

Módulo 6: Saber Analisar e Analisar-se

Ferramentas da WEB 2.0

Avaliação Qualitativa

Avaliação Mediadora

Novo Processo Didático: Avaliação

Projeto Educacional

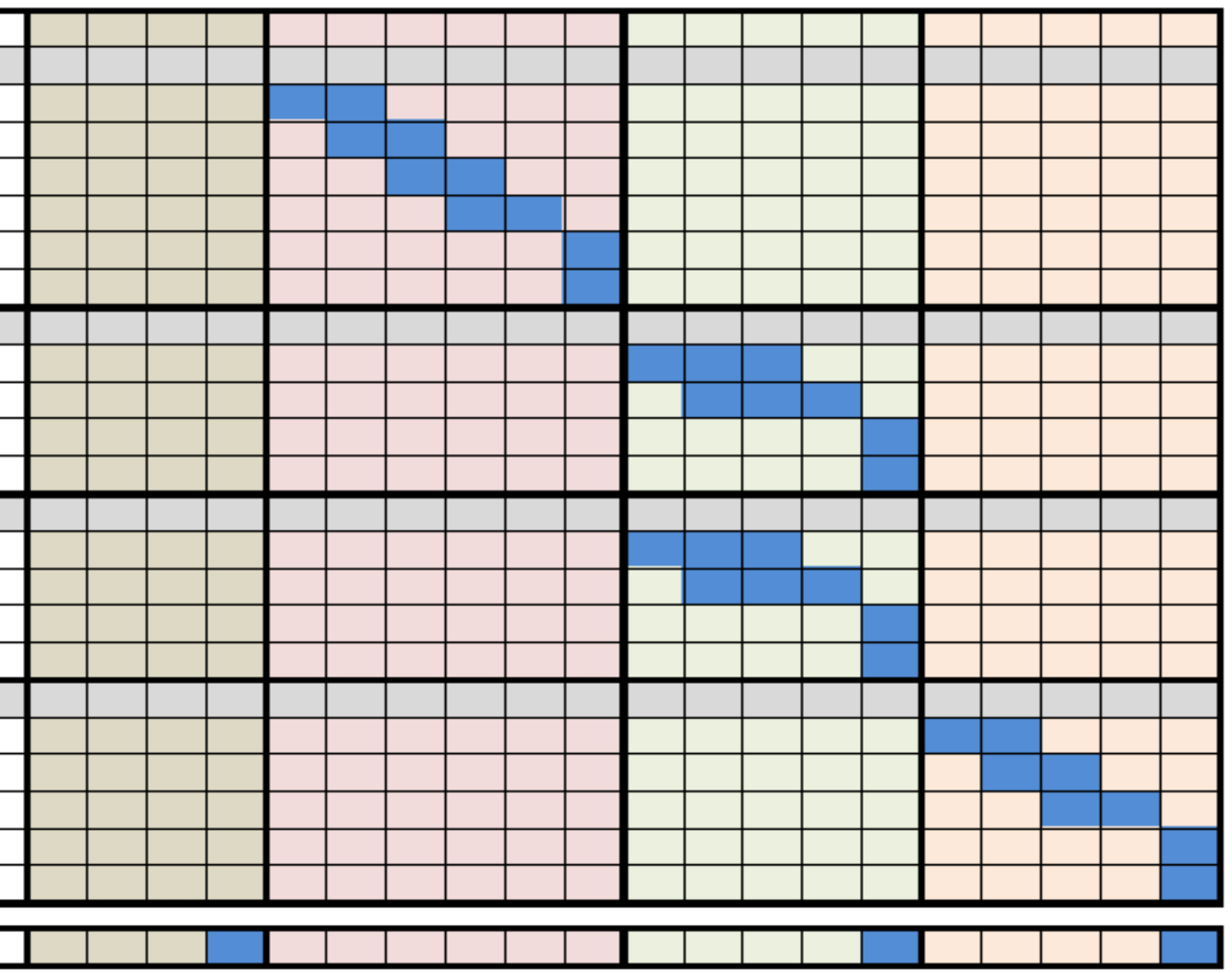

Encontros Presenciais

Tabela 7: Cronograma Geral da Formação Continuada para Professores Imigrantes Digitais 


\section{Considerações Finais}

O dever de ensinar com sucesso, sem se esgotarem as forças ao trabalhar diligentemente e sem enfadonho dispêndio de tempo e fadiga e possibilitar aos alunos sem dificuldade, sem tédio, sem gritos e sem pancadas, como que divertindo-se e jogando, ser conduzidos para os altos cumes do saber, foram dois dos desejos de Comenius (2002 [1621-1657]) na didática magna e continua a ser o desejo do professor e do aluno contemporâneo.

Os benefícios desta pesquisa e seu plano de ação inovadora possuem cinco pilares a serem beneficiados. Os alunos, que inicialmente obterão mudanças no processo de aprendizagem, tornando-se autônomo, criador e ator principal de seu desenvolvimento cognitivo, com isso atingindo melhores resultados acadêmicos, aumento de interesse e frequência na sala de aula; aos professores esperamos oferecer-Ihes subsídios que torne suas aulas mais interativas e dinâmicas, enquanto forem auxiliados por esta formação que o situe acerca das TIC's, da cultura do conhecimento e do comportamento tecnológico dos discientes e, a partir disso, aumentar seu nível de satisfação no seu trabalho. São inúmeros os professores que abandonam a sala de aula, para as mais diversas atividades, quando não são afastados por motivos de saúde; e ambos, a maior parte dos relatos converge para o excesso de trabalho, falta de interesse dos alunos e dispersão pelos aparelhos eletrônicos, suposta causa do baixo rendimento escolar. Esperamos o aumento da autoestima e da competência em processos básicos dos professores imigrantes digitais que estavam totalmente à margem das TIC's. Esta inserção possibilitará novos contatos profissionais e pessoais, maior espaço de pesquisa e conhecimento e sentir-se pertencente, útil e autônomo diante da sociedade contemporânea.

Esperamos maior impacto de produção de conhecimento na Escola, possibilitando tornar-se referência e indispensável ao contexto de educação moderna perpassada por objetos de aprendizagem digitais, mídias e ferramentas da WEB 2.0. Contribuiremos para o desenvolvimento da indústria do nosso estado e nação na medida em que docentes preparados tendem a preparar alunos criativos e aptos para agir nas novas carreiras e empreendimentos do futuro. Por fim, se beneficiará nossa nação, pois abarcará maior consumo das TICs, pesquisas e insumos para manter a sua soberania pela educação e cultura.

Assim, TIC's transformadas em Tecnologias Educacionais se apresentam hoje como possibilidade de solução aos anseios do aluno, que padece pela falta de interesse, e do professor, que assiste ao acúmulo de trabalho e de demanda ao conhecimento. E neste formato de Formação Continuada proporcionamos um eixo seguro para a mudança dos paradigmas da educação para o desenvolvimento de uma educação significativa e prepara para atender as inéditas demandas destes novos tempos modernos. 


\section{Referências Bibliográficas}

ARISTÓTELES. Poética. In: Aristóteles. Col. Os Pensadores. (trad. Baby Abraão). São Paulo, Nova Cultura, 2004.

BONIOLI, D. Os compartilhamentos dos Memes no Facebook: uma análise da formação estrutural, divulgação e replicação como um sintoma normal da adolescência. 2012. Acessado em 04/12/2013. Disponível em: < http://www.ismc.com.br/site/index.php/artigos-mais-lidos/12-psicologia/108compartilhamentos-memes>

CAMPOS, G. H. B. ; ROQUE, G. O. ; ARAUJO, R. ; PERPETUO, C. ; AMARAL, S. B. Tecnologias em Educação: uma experiência em larga escala de formação de professores para o uso de tecnologia em sala de aula. In: Coordenação Central de Educação a distância PUC-Rio. (Org.). Educação a Distância e Formação de Professores: relatos e experiências. $1^{\underline{a}}$ ed. Rio de Janeiro: Editora PUC-Rio, 2007 , v. 1, p. $97-116$.

CENTRO DE PESQUISAS SOCIAIS, FGV. Motivos da Evasão Escolar, 2009. Disponível em: http://www.cps.fgv.br/cps/tpemotivos/. Acessado em 12/11/2013

COMENIUS, J. A. Didática Magna [1621-1657]. 2ª ed. São Paulo: Martins Fontes, 2002.

FORTALEZA, W. C. Educação e Religião em Comenius na sua Didática Magna. 2010. Dissertação (Mestrado) - Faculdade de Humanidades e Direito, Universidade Metodista de São Paulo, São Paulo, 2010.

DEMO, P. Educar pela pesquisa. 9. Ed. Revista. Coleção Educação Contemporânea. Campinas, SP: Autores Associados, 2011

LEAL, J; ALVES, L; HETKOWSKI, T. Educação e tecnologia: rompendo os obstáculos epistemológicos. In: Práticas Pedagógicas e Tecnologias Educacionais.Org: SANTOS, E; ALVES, L. Rio de Janeiro: E-papers, 2006.

LELIS, I. Trabalho, Escola e Formação de Professores. In: Revista Cocar v.2, n.3, jan/jun 2008, 5966. Acessado em 12/11/2013. Disponível em: <http://paginas.uepa.br/seer/index.php/cocar/article/view/120/98>

Do ensino de conteúdos aos saberes do professor: mudança de idioma pedagógico? In: Revista Educação \& Sociedade. Ano XXII, n. 74, abril 2001, 43-58. Acessado em 12/11/2013. Disponível em: <http://www.scielo.br/pdf/es/v22n74/a04v2274>

PROVENZANO, M. E.; WALDHELM, M. Aprender e ensinar a aprender diante dos desafios das TICs. In: Práticas Pedagógicas e Tecnologias Educacionais.Org: SANTOS, E; ALVES, L. Rio de Janeiro: Epapers, 2006. 


\section{Apêndice A}

Esta pesquisa foi elaborada pelo autor, no modelo de questionário fechado e no formato de resposta ao item. A mídia utilizada foi o Formulário, do Google Drive, divulgado por meio do e-mail corporativo.

\section{Pesquisa aos Docentes sobre as Tecnologias Educacionais na Unidade Cinelândia.}

1) Turmas em que leciona no SESI Cinelândia:

- Fundamental e Médio

- Educação Complementar

- Alfabetismo

2) Sexo

- Masculino

- Feminino

3) Assinale sua faixa etária

- 20 a 30

- 31 a 40

- 41 a 50

- 51 a 60

- Acima de 60

4) Na sua formação inicial você estudou sobre as Tecnologias Educacionais na sala de aula?

- Sim, estudei e me senti preparado

- Não, não estudei

- Sim, estudei, mas não me senti preparado

5) Você acredita que a inclusão das Tecnologias da Informação e Comunicação (TIC's) favorecem à educação?

- Sim, acredito

- Não, não acredito

6) Antes das Oficinas de Tecnologias Educacionais oferecidas pelo SESI você se sentia preparado(a) para utilizar as TIC's na sala de aula?

- Sim

- Não

7) Depois das Oficinas de Tecnologias Educacionais oferecidas pelo SESI você se sentiu mais preparado para atuar na sala de aula com os recursos tecnológicos?

- Sim

- Não

8) Você acredita que seja necessário uma NOVA postura didática para a utilização das Tecnologias Educacionais na sala de aula?

- $\operatorname{Sim}$

- Não

9) Antes das Formações Continuadas você já havia utilizado alguma ferramenta tecnológica na sala de aula? (Exclui o Datashow e Filmes)?

- Sim

- Não

10)Depois das Formações Continuadas você passou a utilizar ferramentas tecnológicas na sala de aula?

- $\operatorname{Sim}$

- Não 
11) Você acredita que a limitação do professor sobre o conhecimento da ferramenta tecnológica é um empecilho para o uso como Tecnologia da Informação?

- $\operatorname{Sim}$

Não 